\title{
电力配电网供电可靠性问题探讨
}

\author{
陈建磊 \\ 江苏金智科技股份有限公司 \\ DOI:10.32629/hwr.v3i9.2382
}

[摘要] 电力是生活、生产中不可缺少的能源, 且随着电能使用量的增加, 配电网供电的安全性也受到了人们的重视。配电网 作为电力系统中较为重要的组成部分, 供电可靠性不仅关系到整体供电质量,同时也关系着企业的正常生产及人们的日常生 活。不过目前配电网供电系统仍存在一定的不足,本文就对配电网供电可靠性的问题及对策进行分析, 以供借鉴。

[关键词] 配电网; 供电可靠性; 对策

配电网作为电力系统的重要组成部分, 担负着城乡供电 的重要使命。为此有必要对供电可靠性进行研究探讨, 分析 和解决其中存在的问题, 这样才能更好的加强配电网供电的 及时性和有效性, 为人们的生产、生活提供保障。

\section{1 配电网供电可靠性}

配电网供电可靠性指的是按照国家规定要求对所在区 域的用户实行不间断电量供应的一种能力。配电网本身就是 一个结构复杂、功能多样的系统, 为了保证供电质量, 需要对 供电可靠性予以及时准确的评估, 确保电能供应满足用户的 实际需求, 进而在此基础上, 获取较多可靠的用电信息, 为供 电模式的优化提供帮助。

\section{2 配电网供电可靠性的影响因素}

\section{1 自然因素}

配电网一般被设置在较为偏僻的区域内, 很容易受到区 域气候及地理环境等自然因素的影响而发生不同变化, 进而 影响配电网供电质量。所以需要对自然因素实行及时的分析 和统计, 了解区域天气变化特征, 并制定合理的防控措施, 降 低自然因素的不良影响。

\section{2 配电网结构}

配电网结构的种类和形式较多, 最常看到的有辐射性结 构、环网结构、树干型结构、网状结构、复合结构这几种。 结构形式的不同, 配电网运行中产生的负荷也会存在差异, 相应的与电源的连接方式也会存在不同, 需要结合电力系统 的具体要求, 合理选择配电网结构形式。在众多配电网结构 中, 树干型结构在回路设置中, 会存在很多的复合线, 一旦其 出现问题, 将会对整条线路的供电效果带来影响, 尤其是在 接近回路根部的点出现故障时, 影响效果最为明显, 配电网 的供电可靠性有所下降。

\section{3 设施故障}

一是外力破坏导致的故障。在外力作用下配电网存在的 线路故障, 轻则会造成停电事故, 重则会导致配电网系统荷 载增加, 降低内部设备的运行效果, 影响供电的稳定性。而导 致外力产生的因素有很多, 物品因素, 如风筝、彩带与供电线 路的别蹭等; 违法行为, 如偷电等; 还有因车辆及工程施工 带来的破坏等。
二是内外电压影响。额外电压的影响主要分为两部分, 一个是雷电问题带来的影响。主要是由于直击雷或间接雷 击造成的。直击雷在击中配电网后, 会使系统内部电压出现 不平稳波动, 进而阻碍内部设施的正常运行, 降低供电可靠 性。间接雷击则是由于雷电击中地面后产生的电磁场耦合 现象, 导致配电网电压升高, 这时如果防雷设施不合理, 很容 易出现反击或闪络问题, 破坏供电效果。另一个是由于铁磁 谐振过电压带来的影响。该情况的出现会直接造成配电网电 压不稳, 破坏供电稳定性。而出现该现象的主要原因为互感 器、变压器等原件中的铁芯出现非线性变化, 影响回路中的 电感参数, 在一定谐振条件下, 引起铁磁谐振, 最终导致配电 网供电故障。

三是老化。绝缘设备老化也是影响配电网供电可靠性的 重要原因。当绝缘设备出现绝缘击穿、线路老化或检修不及 时情况时, 会使配电网出现各种故障, 影响供电效果。

四是软件缺陷。配电网的自动化系统的不健全、运行及 管理模式老旧、维修养护水平不足都是导致配电网供电缺乏 可靠性的主要因素。由于软件系统的限制, 配电网运行中很 多问题无法得到及时解决, 进而破坏整体供电效果。

\section{3 配电网供电可靠性的提升措施}

基于以上分析可以看出, 诸多因素都会对电力配电网供 电可靠性产生影响, 故而下面笔者就将从建立完善的配电网 供电管理体系、故障设备的专项整治以及优化配电网结构等 方面来进行配电网供电可靠性的提升措施进行论述。

3. 1 建立完善的配电网供电管理体系

为了加强配电网供电的可靠性, 首要工作就是建立完善 的配电网供电管理体系, 明确管理目标, 建立专门的管理机 构, 并加强专业人员的配备, 确保管理工作的有效落实, 及时 进行供电数据的整理、分析和处理, 从而改善配电网供电模 式, 提高供电质量。同时还要建立长效考核机制, 加大细节处 理力度, 以加强配单网供电的可靠性。

\section{2 故障设备的专项整治}

首先, 开展防雷差异化及老旧设备的整治工作。结合避 雷设备的安装要求对每段线路的雷击情况实行检查, 并根据 实际设置合理的避雷设备, 降低雷击对线路的影响。同时还 
应合理规划接地电阻, 及时消散雷击带来的影响, 保证供电 稳定性。

其次, 加强通道隐患的整治。开展树线隐患排查治理工 作, 列出隐患清单, 并有针对性的制定合理的整治措施, 从而 削弱配电网运行的危险性, 确保电能的正常供应。

再次, 加大外破隐患点的排查力度。一方面要加强配电 网设备的监督和检查, 对设备中存在的故障问题予以及时解 决和处理; 另一方面要做好安全隐患的跟踪, 及时了解隐患 处理情况, 并在工作完成后, 编制详细报告上交领导部门审 批。另外, 制定应急预案, 对出现的突发事故予以快速处理, 避免问题扩大带来不良影响。

最后, 提升配电网系统的自动化水平。加大自动化设备 的应用, 构建完善的自动化监管系统, 对配电网运行中存在 的故障问题进行及时检测和上报, 便于工作人员在第一时间 制定合理解决措施, 从而降低故障影响, 保证配电网的运行 质量。

\section{3优化配电网结构}

一是要加强配电网结构规划设计的合理性。在配电网结 构规划设计中, 应结合具体要求合理规划设计内容, 加大重 点事项的管控力度, 增强配电网供电的可靠性。同时还要根 据配电网的发展情况, 对配电网结构规划设计内容进行优化 和更新, 保证结构设计的合理性、科学性。

二是综合分析生配电网结构的规划情况。在配电网结构 设计中, 需要对变电站规模、线路布局及接线方式等内容实 行综合研究, 并在可持续发展理念的引导下, 开展配电网结 构规划, 确保供电的稳定性和可靠性, 提高配电网的整体运
行质量。

三是合理改造低压配电区。工作人员要优化传统的低压 配电结构形式, 合理选择设备类型, 且完善供电半径的规划 水平, 加强低压配电区改造和设计的标准性, 实现模块化管 理。同时还需对配电方式实施优化处理, 提高系统运行的灵 活性。

\section{4 结语}

鉴于配电网在电力系统运行中的重要性, 在设计规划过 程中, 应对其供电可靠性实行分析研究, 并针对其中存在的 影响因素制定科学合理的解决方案, 以此改进配电网的运行 质量, 提升整体供电水平。

\section{[参考文献]}

[1]巴衣尔,王东, 郭建勧.电力配网存在的不足与电力配 网可靠性的提升研究 [J].技术与市场,2018,25(04):93+95

[2]张涁芳.提高电力配网可靠性的技术措施[J].中外企 业家,2017,(17):165

[3]赵嘉.基于配电网规划提升配网可靠性[J].山东工业 技术,2018,(08):166.

[4]冯中.配电网规划提升配网可靠性的研究 [J].中国新 技术新产品,2018,(18):81-82.

[5]超.影响 $10 \mathrm{kV}$ 配电网可靠性的因素及改进措施 [J]. 北京电力高等专科学校学报:自然科学版,2012,(12):75.

[6]关海亮,王世玲.浅谈影响 10kV配电网供电可靠性的 因素及改进措施[J].电子制作,2015,(9):1-2.

[7]曾军.影响配电网供电可靠性的因素及提高供电可靠 性的措施分析[J].通讯世界,2016,(19):225-226. 